Portland State University

PDXScholar

$1-1-2003$

\title{
Distress under Duress: The Relationship between Campus Climate and Depression in Asian American College Students
}

Christine M. Cress

Portland State University

Elaine Kimiko Ikeda

Follow this and additional works at: https://pdxscholar.library.pdx.edu/elp_fac

Part of the Educational Leadership Commons, Higher Education and Teaching Commons, and the Other Psychiatry and Psychology Commons

Let us know how access to this document benefits you.

\section{Citation Details}

Cress, C. M., \& Ikeda, E. K. (2003). Distress under Duress: The Relationship between Campus Climate and Depression in Asian American College Students. NASPA Journal (National Association Of Student Personnel Administrators, Inc.), 40(2), 74-97.

This Article is brought to you for free and open access. It has been accepted for inclusion in Educational Leadership and Policy Faculty Publications and Presentations by an authorized administrator of PDXScholar. Please contact us if we can make this document more accessible: pdxscholar@pdx.edu. 


\title{
Distress under Duress: The Relationship between Campus Climate and Depression in Asian American College Students
}

\author{
Christine M. Cress \\ Elaine K. Ikeda
}

\begin{abstract}
Student perceptions of negative campus climate were predictive of Asian American students' depression levels in spite of students' entering proclivities toward depression and in spite of varying institutional types. In addition, these findings were consistent whether individual Asian American perceptions of campus climate were entered into the equation or whether institutional levels of campus perceptions (which included all racial and ethnic groups) were entered into the equation. Therefore, higher education institutions that are perceived by students to discriminate against individuals based on race or ethnicity, gender, sexual orientation, or disability may put their Asian American students at risk for severe psychological consequences. Implications for mental health services are discussed.
\end{abstract}

While many higher education institutions across the country have made efforts at becoming "inclusive" multicultural learning environments, incidents of discrimination and prejudice continue to be prob-

Christine M. Cress is an assistant professor for the Postsecondary, Adult and Continuing Education Program, School of Education at Portland State University; and Elaine K. Ikeda is the executive director for California Campus Compact. 
lematic (Reisberg, 1998; Wilson, 1998). For example, perceptions of the "over-representation" of Asian American students in some colleges and universities have resulted in exclusionary changes in admissions policies (Wang, 1993, 1995) and in acts of bigotry and violence directed at Asian American students (Kiang \& Lee, 1993; Nakanishi, 1995). Not long ago, minority student leaders at Boston College were targeted via hate e-mail that read, "college is for "White men"', and that told the minority student leaders to "go back to where you came from" (Chronicle of Higher Education, 1998). Further, all too often multicultural issues get dichotomized into Black and White racial tensions, excluding the unique perceptions and experiences of other racial and ethnic groups (Chang, Witt-Sandia, Jones, \& Hakuta, 1999).

To their credit, a number of higher education institutions have assessed their own campus climates (Arnold, 1995; Jing, 1995; Takahata \& Armstrong, 1996), but few studies have examined the effect of campus climate on student development, and even fewer have assessed the effects of discriminatory and prejudicial climates on students' psychological well-being across racial and ethnic groups. Moreover, since the literature has indicated that Asian Americans are less likely than other groups to use mental health services (Solberg, Chois, Ritsma, \& Jolly, 1994; Solberg, Ritsma, Davis, Tata, \& Jolly, 1994), Asian American college students may be at significant risk on campuses for suffering under the psychological burden of discrimination. Therefore, this study sought to examine student perceptions of campus climate and how these perceptions specifically affect Asian American college students' mental health and individual levels of depression.

\section{Theoretical Perspectives}

\section{Asian Americans}

Until the 1970s, Asian Americans were represented in relatively small numbers on college campuses. However, between 1970 and 1980 the Asian American population increased nationally by $128 \%$, from 1.5 million to 3.5 million, largely due to immigration. In the fall of 1976, there were 150,000 Asian American undergraduates in American higher education institutions nationwide. Ten years later, there were almost three times as many $(488,000)$ Asian Americans in colleges and 
universities across the country (Hsia \& Hirano-Nakanishi, 1995). According to Ong and Hee (1993), the population of Asian and Pacific Americans will have a percentage growth of over 150\% in the next 25 years - a trend certain to effect higher education since presently $40 \%$ of Asian Americans enroll in college at some point in their life (Escueta \& O’Brian, 1995).

The term "Asian American" encompasses many ethnic groups (e.g., Chinese, Japanese, Filipino, Korean, Vietnamese, Asian Indian, Hmong, Laotian, Cambodian, Guamanian) (Nakanishi \& Nishida, 1995), and there is large within-group variation in educational achievement and family income, as well as other differences between Asian American ethnicities (Jones, 1990; Sue \& Sue, 1989). Still, over the past three decades Asian Americans have often been viewed as a "model minority" (Solberg et al., 1994; Uba, 1994). The term "model minority" is associated with Asian Americans because of their purported ability to overcome their minority disadvantage through personal determination, motivation, and hard work (Kitano \& Sue, 1973; Sue, 1981; Sue \& McKinney, 1975) and their supposed high occupational status, higher-than-average family incomes, and lower rates of mental disorders (Sue \& McKinney, 1975; Uba, 1994). Indeed, the model minority myth has caused many to view Asian Americans as having few social and psychological problems (Crystal, 1989).

Contrary to this myth, research indicates that Asian Americans do experience psychological and social problems (Leong, 1986; Sue \& McKinney, 1975; Tracey, Leong, \& Glidden, 1986). Studies have found that Asian Americans must contend with a number of stressproducing issues that most Americans do not: minority status, racism, cultural conflicts, immigrant status, and refugee experiences (Atkinson \& Gim, 1989; Uba, 1994). The effect on college campuses is that Asian American students may experience more acute distress in the midst of their learning environments than other students (Sue \& Frank, 1973). To make matters worse, there has been a nationwide increase in the number of hate crimes committed against Asian Americans in recent years, and Asian American college students in California report more personal experiences with racism than any other group (Uba, 1994). 


\section{Learning Environments}

Since "our surroundings have a great deal to do with the development of our intellectual powers and personality patterns" (Walsh, 1973, p.1), students' personal as well as academic development appears to be intricately linked both with how they perceive and how they interact with their learning environments. Indeed, a 1992 survey indicated that up to 39\% of adolescents and college students may be affected by nonclinical depression, which has shown to be related to general malaise about studying and using effective study habits (Drodz, 1994). More recently, Cress (1999) found a significant positive correlation between college student reports of feeling depressed and students' likelihood to not attend class or complete their homework.

Ponterotto (1990) has suggested that higher dropout rates for racial and ethnic minority students are a result of inhospitable campus climates at most of the predominately White college campuses. Confirming this perspective, Jing (1995) found that 39\% of students reported being discriminated against at least once in college because of their race, gender, age, or disability, even though students gave high ratings to instructors' skill level and level of preparedness in the classroom. Similarly, Arnold (1995) found that 40\% of the students indicated that college was not a hospitable place for gays, lesbians, and bisexuals. In other words, it appears quite clear that certain subgroups of students are still plagued on college campuses by various forms of discrimination, and racial and ethnic minority students are still often made to feel as "outsiders" or "the other" (Soloranzo, 1997). This can result in students' feeling personally invalidated, the effects of which can have detrimental psychological and educational consequences.

\section{Sense of Self and Educational Outcomes}

The kind of integration (Tinto, 1987) and engagement (Astin, 1993b; Pace, 1984) that students experience with their academic community can affect both their sense of self as well as their educational development. Previous research has noted a clear relationship between students' emotional health and self-concept (Goldman \& Wong, 1997). For example, individuals who are high in self-esteem tend to be at a lower risk for depression (Crandall, 1973), and for experiencing feelings of hopelessness (Abramson, Metalsky, \& Alloy, 1989). They also tend to experience more positive affect (Pelham \& Swann, 1989). 
Students' positive affect and self-concept has also been shown to be predictive of college academic achievement (Blustein \& Palladino, 1991; Coleman, 1968; Epps, 1969; Reynolds, 1988; Trent, 1970), including issues related to retention (Biddle, Bank, \& Slavings, 1987; Brockner, 1985; Hoffman, 1984). Moreover, students who perform well in their courses tend to report close relationships with peers and high levels of interaction with faculty members (Spring, 1994)—variables known to be correlated with academic success (Astin, 1993a).

On the other hand, students with poor self-concept have been found to earn lower grades (Lent, Brown, \& Larkin, 1984), are less likely to persist in technical and scientific majors (Blustein et al., 1986), and are less likely to perform well in mathematics courses (House, 1994). In addition, research on college students' psychological distress has found that internal locus of control is positively correlated with buffering the effects of external negative events (Cummins, 1989). Consequently, college students without a strong internal locus of control are more inclined to depression, which has been linked with eating disorders (McNamara, 1989), alcohol abuse (Kashubeck \& Christensen, 1995), lack of concentration and successful academic performance (Haines, 1996), and suicide (Waelde, 1994). In addition, one study comparing Japanese American and Anglo American university students found that "Japanese American students reported less self-esteem and more anxiety than Anglo American students" (Powers, Choroszy, \& Douglas, 1987, p. 21).

\section{Methodology}

\section{Data Source}

The study used a longitudinal national sample of students surveyed at two different points: 1993 (at the time of college entry) and 1997 (four years after matriculation). Data on the students were collected by the Cooperative Institutional Research Program at the Higher Education Research Institute at the University of California, Los Angeles.

\section{Variables and Method of Analysis}

In the 1997 Senior Survey, students were asked to report if during the past year they felt depressed and how often. Students were also asked 
to indicate their agreement with each of the following sets of statements: (1) I have been singled out in class or treated differently than other students because of my gender, race, or ethnicity; (2) many students on campus are prejudiced against women or racial and ethnic minorities; (3) instructors treat students the same regardless of the students' gender, race, or ethnicity; and (4) I have observed discriminatory words, behaviors, or gestures directed toward students who are women, ethnic or racial minorities, gays or lesbians, or people with disabilities.

In order to measure students' perceptions of campus climate, the campus climate survey items were treated as a single aggregate variable. This was determined since the campus climate survey items based on individual student scores are highly intercorrelated and an exploratory factor analysis on the items did not reveal any distinct composite factors. The scale yielded a strong reliability score (alpha=.8591). Therefore, for the purposes of the study, campus climate was defined as the total set of responses to the campus climate questions, with two of the variables (instructors treat students the same regardless of gender or race) recoded in the same direction as the other survey items so that the final composite variable of campus climate reflects a negative or discriminatory climate.

The analysis for this study consisted of two parts. First, a descriptive analysis was performed using crosstabulations to examine students' reported levels of depression and perceptions of campus climate. Second, linear stepwise regressions were used to predict what factors are associated with Asian American college students' levels of depression.

Are these factors personal in nature, related to institutional type or structure, related to faculty attitudes and behaviors including interactions with students, related to student levels of involvement, or related to perceptions of discrimination and prejudice on campus? In addition, might some of these factors, such as interacting with faculty or getting involved in campus activities, mediate the impact of negative campus climate on student depression?

Stepwise regression was selected as the analysis technique because this procedure offers the opportunity to follow changes in the standardized 
regression coefficients and to observe how intercorrelations among independent variables influence their respective predictive ability.

The dependent variable "felt depressed" was coded: (1) not at all, (2) occasionally, and (3) frequently. Two separate regressions were performed to test: (1) whether individual Asian American student perceptions of a discriminatory campus climate affect individual feelings of depression and (2) whether collective perceptions of discriminatory campus climate (the average perception of all students at each institution) affect Asian American students' feelings of depression. In essence, using the collective perceptions of campus climate allowed the researchers to examine whether individual Asian American students interpret the campus climate differently than their classmates.

Also, since certain types of students may be predisposed to perceiving campus climate in particular ways, various student background characteristics were entered into the regression first. By controlling for these entering characteristics, the relationship between the dependent variable and other independent variables was examined. Further, additional independent variables that may affect students' depression levels were included in the analysis (see below) in order to ascertain the actual impact of campus climate on individuals' mental health.

The independent variables included:

- personal background characteristics (gender, mother, and father educational levels, high school GPA, freshman social and academic self-concept, and self-reports of depression and feeling overwhelmed during high school),

- institutional characteristics (institutional type, control, selectivity, and size),

- faculty perceptions of the institution (prestige-oriented institution, institutional commitment to diversity, social change oriented institution, student-centered faculty, and respectful interactions campus),

- current academic major (sixteen aggregated fields), and

- college involvement and experiences (professional support from faculty, interpersonal relationship with faculty, independent learner, 
collaborative learner, academically disengaged, leadership activities, multicultural involvement, politically active, and substance user).

Finally, the last variable, perceptions of campus climate, was used for separate analyzes at the individual level and at the collective institutional level. Within each block, the independent variables were tested for stepwise entry using a confidence level of $\mathrm{p}<.05$. Listwise deletion resulted in 508 cases.

\section{Results}

\section{Descriptive Analyses}

As Tables 1 and 2 indicate, Asian American students ( $\mathrm{n}=508)$ are more likely than all other students combined to experience feelings of depression as well as to perceive negative campus climates. These findings are consistent with previous research that indicated that Asian Americans may suffer from greater amounts of emotional disturbance than the rest of the population (Sue \& Kirk, 1972, 1973; Tracey, Leong, \& Glidden, 1986). Further, when the mean scores of depression and negative campus climate perceptions are compared between Asian American students and other students, the differences are statistically significant $(\mathrm{p}<.01)$.

Additional descriptive analyses were next conducted to examine the relationship between Asian American student levels of depression and perceptions of a discriminatory campus climate. Pearson productmoment (pairwise) correlations indicate a positive relationship between perceptions of discrimination on campus and Asian American students' reported occurrence of depression (Table 3). Interestingly, this relationship was stronger for Asian American men than for their female counterparts. This is surprising given that female college students are more likely to report experiencing feelings of depression than are male college students (Sax, Astin, Korn, \& Mahoney, 1999). 
Table 1

College Student Reports of Feeling Depressed

\begin{tabular}{lccc} 
& \multicolumn{3}{c}{ Percentage of Frequency } \\
\cline { 2 - 4 } & Not at All & Occasionally & Frequently \\
\hline Asian American & & & \\
Men & 25.6 & 66.1 & 8.4 \\
Women & 18.7 & 72.3 & 9.0 \\
& & & \\
All Other College Students & & \\
Men & 34.1 & 59.7 & 6.1 \\
Women & 22.0 & 69.1 & 8.8 \\
\hline
\end{tabular}

(a) excludes Asian American students

Table 2

Mean Campus Climate (negative climate) by Sex

\begin{tabular}{|c|c|c|c|c|c|c|}
\hline & \multicolumn{2}{|c|}{ Mean Score } & \multicolumn{2}{|c|}{ Std Dev } & \multicolumn{2}{|c|}{$\mathbf{n}$} \\
\hline & Men & Women & Men & Women & Men & Women \\
\hline Asian American Students & 21.91 & 22.36 & 6.54 & 6.65 & 226 & 282 \\
\hline All Other College Students & 20.13 & 20.73 & 6.16 & 6.56 & 3,754 & 4,699 \\
\hline
\end{tabular}

Note: mean score is total average responses to all campus climate survey questions.

Table 3

Correlations of Depression with Negative Campus Climate by Sex

Correlation with Negative Climate Depressed $^{\text {a }}$

\begin{tabular}{cr}
\hline Asian American & \\
Men & .2435 \\
& $\mathrm{p}=.000$ \\
Women & .1894 \\
& $\mathrm{p}=.001$ \\
\hline
\end{tabular}

(a) indicates level of occurrence in past year: 1-not at all, 2-occasionally, 3-frequently. 
While self-reports of depression are certainly not equivalent to clinical diagnoses, few studies have examined the antecedents of depression for college students and what factors might facilitate depression during the undergraduate years. Therefore, multivariate analyses were employed to further examine what variables predict depression in Asian American students and to identify the role that campus climate plays in students' emotional and psychological health.

\section{Multiple Regressions}

Regression analyses indicate that perceptions of negative campus climate are significantly related to self-reported levels of depression in Asian American students (Table 4). These findings hold true whether examining individual Asian American student perceptions of climate or whether the collective student perceptions of institutional climate are entered into the equation. These findings support the hypothesis that Asian American students' perceptions of the climate are congruent with those of their classmates.

The final equation for the regression analyses accounted for predicting approximately $19 \%$ of the variance $\left(\mathrm{R}^{2}=.186\right)$ for the analysis using the aggregated (or collective) perception of campus climate, and for approximately $22 \%$ of the variance $\left(\mathrm{R}^{2}=.222\right)$ for the analysis using individual perceptions of campus climate. Seven variables entered the regressions, six of which were significant $(\mathrm{p} \leq .05)$ in the final step for predicting increased levels of depression for Asian American students.

The strongest predictor of depression for Asian American students was freshman reports of feeling depressed ( $\beta=.223$ on the individual level, and $\beta=.227$ on the collective level). Feeling overwhelmed during high school was also predictive of becoming depressed during college ( $\beta=.084$ on the individual level, and $\beta=.108$ on the collective level). However, after statistically controlling for these entering proclivities, campus climate is still a significant predictor of depression. In fact, on the individual level, perceptions of a negative campus climate (hostile and discriminatory) represent the variable with the beta coefficient greatest in magnitude $(\beta=.214)$. Campus climate is also a significant predictor of depression even when using collective perceptions $(\beta=.084)$. 


\section{Table 4 \\ Results of Blocked Hierarchical Regressions-Predicting Feeling Depressed}

Regression with individual and collective perceptions of campus climate.

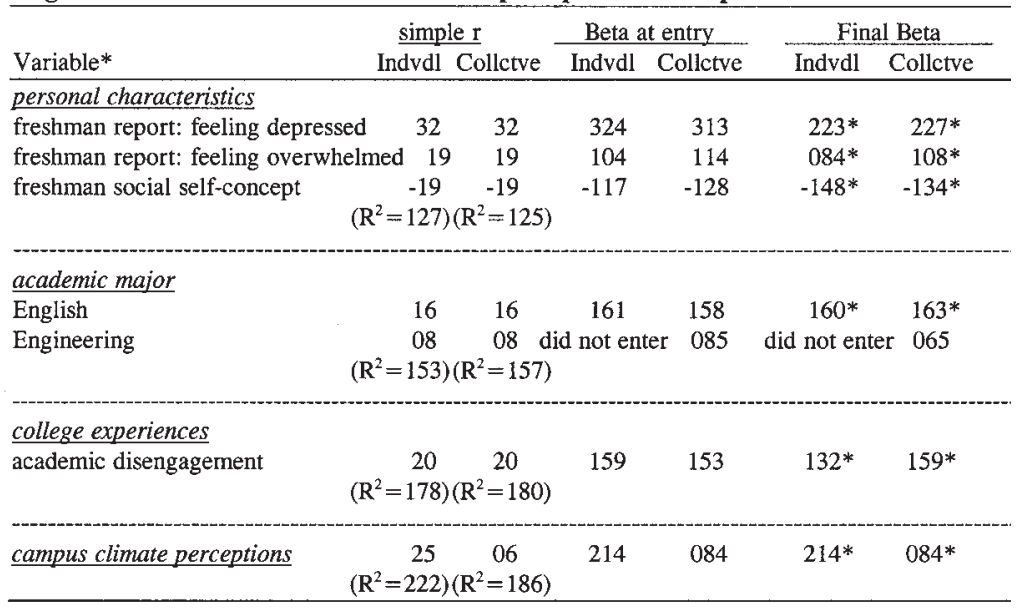

Note: ${ }^{*} \mathrm{p}<.05$, decimals omitted on coefficients.

This is an especially important finding because it could be argued that students who are depressed in high school are likely to have a rather negative outlook on life and therefore perceive more discrimination and hostility on campus, which in turn causes them to feel depressed in college as well. While this scenario seems quite logical, what these regression analyses tell us is that regardless of students' entering psychological state, Asian American students' observations of discrimination and prejudice affect them negatively.

Furthermore, Asian American students are not alone in their perceptions of negative campus climate. When the aggregated variable of campus climate (which takes into account all students' perceptions at an institution) is entered into the equation after controlling for other relevant variables, campus climate continues to have a directly detrimental affect on Asian American students' emotional and psychological state as manifested in self-reports of depression.

Other independent variables, such as the control, type, size, or selectivity of an institution, do not seem to be related to levels of depres- 
sion for Asian American students because none of these variables entered the equation. Nor do faculty perceptions of the same institutions in terms of student-faculty interaction or institutional goals regarding diversity seem to play a major role in students' levels of depression because none of these variables entered the equation.

Regarding student activity levels during college, it appears that depressed students are not very inclined to get involved. Indeed, the factor representing academic disengagement was significantly positively related with depression $(\beta=.132$ at the individual level, and $\beta=.159$ at the collective level). It should be noted that there is a positive zero-order relationship between negative campus climate and academic disengagement $(\mathrm{r}=.125, \mathrm{p}=.004)$. Thus, there is a disconcerting three-way relationship between a negative campus climate, depression, and academic disengagement. Therefore, campus administrators and faculty who tolerate attitudes and acts of discrimination and neglect to create supportive learning environments for all their students are likely to create distress in Asian American students, which is exhibited both as depression and disengagement from their academic pursuits.

Interestingly, as can be seen from the coefficient changes regarding social self-concept, having a positive sense of social self-concept as an entering freshman seems to protect against student depression even in the midst of a negative campus climate. Having a strong social selfconcept upon entering college $(\mathrm{r}=.-19)$ tends to preclude Asian American students from becoming depressed; and it continues to mediate the effects of a hostile campus climate even after the institutional, faculty, and college experience variables are entered into the equation ( $\beta=.-148$ at the individual level and $\beta=.-134$ at the collective level).

Finally, students who major in English also seem to be more at risk for becoming depressed. It would be interesting to further explore what precisely it is about being an English major that adds to the chances of feeling depressed. Do Asian American students not see themselves reflected in the literature? Pinar (1993) believes that the Eurocentric nature of the curriculum denies self-understanding to racial and ethnic minorities. Since Asian Americans earn a higher proportion of their degrees in business and science than in the humanities and social 
sciences, Asian American students who major in English may be suffering from both the lack of a peer group (Escueta \& O'Brian, 1995) and of faculty role models (Astin, Antonio, Cress, \& Astin, 1997). Or, are these students struggling with the challenges of English as a nonnative language? Cultural isolation and lack of proficiency in English have also been linked to depression and emotional distress among Asian Americans (Uba, 1994).

Another possible explanation may be that Asian American students who decide to major in English may be experiencing conflict over selecting their own field in which to major and not yielding to their parents' wishes (Uba, 1994). Many Asian parents immigrated to the United States so that their children could be college-educated and "have a better life than they had" (Mau, 1995). Further, it is not uncommon for Asian immigrant parents to select their children's college majors and career goals (Okagaki \& Frensch, 1998). Therefore, Asian American students who select majors that contradict their parents' wishes may be experiencing greater amounts of stress than their peers. Whatever the case, further research is certainly needed to examine the differences between Asian American students based on academic field of study, perceptions of campus climate, and levels of distress.

\section{Discussion}

The findings from this study clearly point to the detrimental effects of negative campus climate on Asian American students' levels of depression. Negative campus climate was predictive of students' depression levels in spite of students' entering proclivities toward depression and in spite of varying institutional types and faculty attitudes and behaviors. In addition, depressed students tend to become academically disengaged, and perhaps most significant, these findings were consistent whether individual Asian American perceptions of climate were entered into the equation or whether institutional levels of climate perceptions (which included all racial and ethnic groups) were entered into the equation. In other words, Asian American students' experiences and observations of discrimination and prejudice are corroborated by students of differing racial and ethnic backgrounds. 
These results are particularly disconcerting when linked with research indicating that entering freshman across the country report the highest levels of stress in over thirty years (Sax, Astin, Korn, \& Mahoney, 1999). Stress has been directly related to suicide ideation, and additional research indicates that approximately $60 \%$ of college students (Bonner \& Rich, 1987) and 63\% of high school students report some suicide ideation during periods of stress (Smith \& Crawford, 1986; Friedman, Asnis, Boeck, \& DiFiore, 1987). A more recent study has also found that one out of four college students had seriously contemplated suicide within the previous 12 months (Grieger \& Greene, 1998). Further, even a small increase in the number of severely distressed students has profound implications for college counseling centers since these students require appreciably more services than other students, including the need for mental health professionals to work closely with other campus departments such as residence life, security, and health services (Cornish, Riva, Henderson, Kominars, \& McIntosh, 2000).

Although the "model minority myth" perpetuates the belief that Asian Americans do not need mental health services, as this study has shown Asian American students report even higher levels of depression than other students on campus. This is especially disturbing in light of the fact that Asian American students are less likely to seek assistance from campus psychiatric facilities (Atkinson \& Gim, 1989; Sue, 1981; Sue $\&$ Frank, 1973; Tracey et al., 1986) and are reluctant to seek out these services for a variety of reasons including cultural inhibitions about seeking mental health services and shortages of culturally sensitive personnel (Atkinson \& Gim, 1989; Sue \& Frank, 1973; Uba, 1994). Due to the tendency of Asian Americans to maintain social harmony and hide individual emotional expression (Henkin, 1985), students who observe or experience acts of discrimination may be internalizing their feelings rather than seeking support or assistance with the situation.

Equally disturbing is the earlier finding that Asian American males may be more likely to suffer from depression due to the affects of campus climate than Asian American women students. While gender did not enter either of the regression equations, the descriptive results indicated a stronger relationship between depression and campus climate for men, even though male college students are less likely to 
report feelings of depression. Since females are more likely to have positive attitudes toward seeking professional counseling (Tata \& Loeng, 1994; Tedeschi \& Willis, 1993; Schonert-Riechl \& Muller, 1996), providing mental health services outreach and intervention to male Asian American students may be a hidden need on many campuses. Indeed, since Asian Americans are more likely to seek psychological support from familial and social networks than counseling clinics (Atkinson, Whiteley, \& Gim, 1990; Solberg, Choi, Ritsma, \& Jolly, 1994; Yeh \& Wang, 2000), mental health professionals should work closely with leaders of student organizations and campus administrators in preparing them to recognize the signs of depression in Asian American students.

With respect to male Asian American students, student services staff who work with fraternities or other all male groups may have opportunity to provide educational programs on the link between campus climate, depression, and other negative outcomes such as academic disengagement. Tutorial services and academic advisers may need to inquire if Asian American college students' failure to complete homework or attend class are related to feelings of depression because of observations of or experiences of discrimination. Similarly, residence life staff should be alert to students' signs of social and academic disengagement as a possible consequence of student experiences of a negative or hostile campus climate.

Therefore, if Asian American students are experiencing higher levels of depression than their peers, and if they are also less likely to seek help from campus mental health services, then it is imperative that the college environment not exacerbate the situation. As this research has highlighted, it is vitally important that higher education institutions do all that is possible to reduce factors that contribute to a negative campus climate by eliminating prejudicial attitudes and acts. Given the changing demographics of higher education institutions, it seems incumbent upon colleges and universities to critically assess the state of learning environments and to implement policies and programs that create a positive campus climate for all students. Moreover, research has indicated that positive interactions with diverse others leads to growth in a wide range of academic and personal contexts (Smith \& Schonfeld, 2000). In contrast, higher education institutions that are perceived by Asian American students to discriminate against 
individuals based on race, ethnicity, gender, sexual orientation, or disability may put their students at risk for severe academic and psychological consequences.

\section{Limitations and Considerations for Future Research}

There are a number of important factors that could not be addressed in the present study that should be noted for future research and investigation. First, as mentioned earlier, Asian American students are actually an aggregation of a number of very distinct cultural groups that vary in many ways, not the least of which are educational traditions and expectations. The term "Asian American" applies to members of over 25 groups that have been classified as a single group based on a few distinguishing factors: common ethnic origins in Asia and the Pacific Islands and similar physical appearance (Uba, 1994). Asian Americans are culturally and experientially very diverse-differing in degrees of acculturation, occupational skills, cultural values and beliefs, religion, primary language, income, and education to name a few. Thus, future studies would do well to more specifically define the historical and cultural backgrounds of their sample. "Analyzing all Asian Americans together neglects important self-identified differences among the various Asian cultures" (Tracey, Leong, \& Glidden, 1986, p. 332).

Second, Asian Americans are immigrants or descendants of immigrants to the United States and vary substantially in recency of arrival. In the 1960s, Asian Americans constituted 0.5\% of the U.S. population and consisted primarily of descendants of earlier Japanese and Chinese immigrants. By 1990, the number of Asian Americans had increased to $2.9 \%$ of the U.S. population, however, most were foreign born (Uba, 1994). It is important to consider possible generational differences that can occur among Asian American college students that can affect identity, self-concept, and issues of stress.

Third, the aggregated variable representing campus climate is actually a compilation of questions regarding gender, race, ethnicity, sexual orientation, and disability. While an individual student could be affected by any one or all of these dimensions of discrimination, it is 
impossible to know which, if any, plays the more critical role in students' perceptions of campus climate and subsequent depression. For instance, future research explorations might be better served by looking just at racial climate or just at gender climate. Still, since many students are susceptible to being victims of more than one type of discrimination (i.e., gender and racial discrimination), any study that examines the effects of campus climate on student development should take into consideration the possible layers of discrimination.

Fourth, as also noted earlier, students' self-reports of depression should not be equivocated with a trained professional's diagnosis of depression. In fact, students responded to only one item in rating their feelings of depression. Use of a broad range of items addressing feelings and behaviors associated with depression might produce a more accurate representation of depression in lieu of a clinical interview.

Fifth, in 1990 the U. S. Census Bureau reported that of the resident Asian, Pacific Islander population of 7,274,000, 56\% of Asian, Pacific Islanders lived in the Western United States, while only 18\% lived in the North East, 15\% lived in the South, and 11\% lived in the Midwest (U.S. Bureau of the Census, 1992). Therefore, there may also be important regional differences in experience that merit additional exploration (Hsia \& Hirano-Nakanishi, 1995).

Finally, survey questions can only uncover the surface of such complex issues as depression or perceptions of discrimination and prejudice. Future studies would do well to qualitatively investigate the incidents and antecedents of hostile campus climates and how such climates detrimentally affect students.

\section{Conclusion}

The variable representing student perceptions of a negative campus climate entered the regression equation as a statistically significant predictor of Asian American student depression, even after students' entering characteristics and other independent variables such as student activities and academic major were controlled. Thus, while a number of variables contribute to Asian American students' feelings of depression, it can be stated with confidence that a negative campus 
climate has a direct effect on student self-reported depression levels. In fact, outside of students' entering proclivity towards depression, negative campus climate had the strongest effect on Asian American student depression during college. In other words, Asian American college students who are subjected to environments that tolerate prejudice and discrimination pay a psychological toll whether or not such hostile attitudes and behaviors are specifically directed at them. Given the tendency for Asian American students to withhold verbalizing their feelings and reactions, student affairs professionals and peer support services need to be acutely sensitive to the emotional and academic implications of learning environments and the behavioral assumptions under which we function. Student apathy and shyness may be the result of the internalized pain of prejudice and discrimination.

\section{References}

Abramson, L. Y., Metalsky, G. I, \& Alloy, L. B. (1989). Hopelessness depression: A theory-based subtype of depression. Psychological Review, 96, 358-378.

Arnold, C. L. (1995). Chabot college campus climate survey results, fall 1994. (ERIC Document Reproduction Service No. ED 402982)

Astin, A. W. (1993a). Assessment for excellence: The philosophy and practice of assessment and evaluation in higher education. Phoenix: American Council on Education and the Oryx Press.

Astin, A. W. (1993b). What matters in college: Four critical years revisited. San Francisco: Jossey-Bass.

Astin, H. S., Antonio, A. L., Cress, C. M., \& Astin, A. W. (1997). Race and ethnicity in the American professoriate, 1995-96. Los Angeles: Higher Education Research Institute, UCLA.

Atkinson, D. R., \& Gim, R. H. (1989). Asian-American cultural identity and attitudes toward mental health services. Journal of Counseling Psychology, 36, 209-212.

Atkinson, D. R., Whiteley, S., \& Gim, R. H. (1990). AsianAmerican acculturation and preferences for help providers. Journal of College Student Development, 31, 155-161.

Biddle, B. J., Bank, B. J., \& Slavings, R. L. (1987). Norms, preferences, identities and retention decisions. Social Psychology Quarterly, 50(4), 322-337. 
Blustein, D. L., \& Palladino, D. E. (1991). Self and identity in late adolescence: A theoretical and empirical integration. Journal of Adolescent Research, 6(4), 437-453.

Blustein, D. L., Judd, T. P., Krom, J., Viniar, B., Padilla, E., Wedemeyer, R., \& Williams, D. (1986, May). Identifying predictors of academic performance of community college students. Journal of College Student Personnel, 242-249.

Bonner, R. L., \& Rich, A. R. (1987). Toward a predictive model of suicidal ideation and behavior: Some preliminary data in college students. Suicide and Life-Threatening Behavior, 17, 50-63.

Brockner, J. (1985). The relation of trait self-esteem and positive inequity to productivity. Journal of Personality, 53(4), 517-529.

Chang, M., Witt-Sandia, D, Jones, J., \& Hakuta, K. (Eds.) (1999). The dynamics of race in higher education: An examination of the evidence. Stanford, CA: Center for the Comparative Studies on Race and Ethnicity, Stanford University.

Chronicle of Higher Education. (1998, October 16). Minority students target of hate e-mail, Al0.

Coleman, J. S. (1968). Equality of opportunity. Washington, D.C.: U.S. Government Printing Office.

Cornish, J. A. E., Riva, M. T., Henderson, M. C., Kominars, K. D., $\&$ McIntosh, S. (2000). Perceived distress in university counseling center clients in a six-year period. Journal of College Student Development, 41(1), 104-109.

Crandall, R. (1973). The measurement of self-esteem and related constructs. In J. Robinson \& P. Shaver (Eds.), Measures of social psychological attitudes. Ann Arbor: University of Michigan, Institute for Social Research.

Cress, C. M. (1999). The impact of campus climate on students cognitive and affective development. Unpublished doctoral dissertation. University of California, Los Angeles.

Crystal, D. (1989). Asian Americans and the myth of the model minority. Social Casework: The Journal of Contemporary Social Work, 70, 405-413.

Cummins, R. C. (1989). Attributions, outcome expectations, locus of control and daily hassles. (ERIC Document Reproduction Service No. ED309328)

Drodz, G. P. (1994). Is depression related to study habits? (ERIC Document Reproduction Service No. ED389995) 
Epps, E. G. (1969). Correlates of academic achievement among northern and southern urban Negro students. Journal of Social Issues, $25,33-70$.

Escueta, E., \& O'Brian, E. (1995). Asian Americans in higher education: Trends and issues. In D. T. Nakanishi and T. Y. Nishida (Eds.), The Asian American educational experience. New York: Routledge.

Friedman, J. M. H., Asnis, G. M., Boeck, M., \& DiFiore, J. (1987). Prevalence of specific suicidal behaviors in a high school sample. American Journal of Psychiatry, 144(9), 1203-1206.

Goldman, C. S., \& Wong, E. H. (1997). Stress and the college student. Education, 117(4), 604-610.

Grieger, I., \& Greene, P. (1998). The psychological autopsy as a tool in student affairs. Journal of College Student Development, 39(4), 388-392.

Haines, M. E. (1996). The effects of depressed mood on academic performance in college students. Journal of College Student Development, 37(5), 519-526.

Henkin, W. A. (1985). Toward counseling the Japanese in America: A cross-cultural primer. Journal of Counseling and Development, 63, 500-503.

Hoffman, J. A. (1984). Psychological separation of late adolescents from their parents. Journal of Counseling Psychology, 31(2), 170-178.

House, J. D. (1994). The predictive relationship between academic self-concept, achievement, expectancies, and grade performance in college calculus. The Journal of Social Psychology, 135(1), 111-112.

Hsia, J., \& Hirano-Nakanishi, M. (1995). The demographics of diversity: Asian Americans and higher education. In D. T. Nakanishi and T. Y. Nishida (Eds.), The Asian American educational experience. New York: Routledge.

Jing, L. (1995). Cabrillo students' campus climate survey, spring 1995. (ERIC Document Reproduction Service No. ED 405936)

Jones, W. T. (1990). Perspectives on ethnicity. In L. V. Moore (Ed.), New Directions for Student Service (Number 51, 59-72). San Francisco: Jossey-Bass.

Kashubeck, S., \& Christensen, S. A. (1995). Parental alcohol use, family relationship quality, self-esteem, and depression in college students. Journal of College Student Development, 36(5), 431-443.

Kiang, P. N., \& Lee, V. W. (1993). Exclusion or contribution? Education K-12 policy. The state of Asian Pacific America: A public poli- 
cy report. Los Angeles: Leadership Education for Asian Pacifics and the UCLA Asian American Studies Center, University of California.

Kitano, H. H., \& Sue, S. (1973). The model minorities. Journal of Social Issues, 29(2), 1-9.

Lent, R. W., Brown, S.D., \& Larkin, K. C. (1984). Relation of selfefficacy expectations to academic achievement and persistence. Journal of Counseling Psychology, 31(3), 356-362.

Leong, F. T. L. (1986). Counseling and psychotherapy with Asian Americans: Review of the literature. Journal of Counseling Psychology, 33, 196-202.

Mau, R. Y. (1995). Barriers to higher education for Asian/PacificAmerican females. In D. T. Nakanishi and T. Y. Nishida (Eds.), The Asian American educational experience. New York: Routledge.

McNamara, K. (1989). Group counseling for overweight and depressed college women: A comparative evaluation. Journal for Specialists in Group Work, 14(4), 211-218.

Nakanishi, D. (1995). A quota on excellence? The Asian American admissions debate. In Nakanishi, D. T., \& Nishida, T. Y. (Eds), The Asian American educational experience. New York: Routledge.

Nakanishi, D. T., \& Nishida, T. Y. (1995). The Asian American educational experience. New York: Routledge.

Okagaki, L., and Frensch, P. A. (1998). Parenting and children's school achievement: A multiethnic perspective. American Educational Research Journal, 35(1), 123-144.

Ong, P., \& Hee, S. J. (1993). The growth of the Asian Pacific American population: Twenty million in 2020. The state of Asian Pacific America: A Public Policy Report. Los Angeles: Leadership Education for Asian Pacifics and the UCLA Asian American Studies Center, University of California.

Pace, C. (1984). Measuring the quality of college student experiences. Los Angeles: University of California, Higher Education Research Institute.

Pelham, B. W., \& Swann, W. B., Jr. (1989). From self-conceptions to self-worth: On the sources and structure of global self-esteem. Journal of Personality and Social Psychology, 57, 672-680.

Pinar, W. (1993). Notes on understanding curriculum as a racial text. In McCarthy and Crichlow (Eds.), Race and identity. New York: Routledge. 
Ponterotto, J. G. (1990). Racial/ethnic minority and women students in higher education: A status report. New Directions for Student Services, 52, 45-59.

Powers, S., Choroszy, M., \& Douglas, P. (1987). Attributions for success and failure of Japanese-American and Anglo-American university students. Psychology, A Quarterly Journal of Human Behavior, 21(3), $16-23$.

Reisberg, L. (1998, October 2). Seeking acceptance on fraternity row. The Chronicle of Higher Education, A45, 47.

Reynolds, W. M. (1988). Measurement of academic self-concept in college students. Journal of Personality Assessment, 52(2), 223-240.

Sax, L. J., Astin, A. W., Korn, W. S., \& Mahoney, K. M. (1999). The American freshman: National norms for fall 1999. Los Angeles: Higher Education Research Institute, UCLA.

Schonert-Reichl, K. A., \& Muller, J. (1996). Correlates of helpseeking in adolescence. Journal of Youth and Adolescence, 25, 705-731.

Smith, D. G., \& Schonfeld, N. B. (2000). The benefits of diversity: What the research tells us. About Campus, 5(5), 16-23.

Smith, K., \& Crawford, S. (1986). Suicidal behavior among "normal" high school students. Suicide and Life-Threatening Behavior, 16(3), 313-325

Solberg, V.S., Chois, K-H, Ritsma, S., \& Jolly, A. (1994). AsianAmerican college students: It is time to reach out. Journal of College Student Development, 35, 296-3-1.

Solberg, V. S., Ritsma S., Davis, B. J., Tata, S. P., \& Jolly, A. (1994). Asian American students' severity of problems and willingness to seek help from university counseling centers: Role of previous counseling experience, gender, and ethnicity. Journal of Counseling Psychology, $41(3), 275-279$.

Soloranzo, D. G. (1997). Images and words that wound: Critical race theory, racial stereotyping, and teacher education. Teacher Education Quarterly, 24(3), 5-19.

Spring, L., \& others (1994). Influences on college students' orientations toward learning for self-understanding. Paper presented at the American Educational Research Association, New Orleans, LA. (ERIC Document Reproduction Service No. ED 368 266)

Sue, D. W. (1981). Counseling the culturally different: Theory and practice. New York: John Wiley \& Sons. 
Sue, D. W., \& Frank, A. C. (1973). A typological approach to the psychological study of Chinese and Japanese American college males. Journal of Social Issues, 29(2), 129-149.

Sue, D. W., \& Kirk, B. A. (1972). Psychological characteristics of Chinese-American students. Journal of Counseling Psychology, 29(6), 471-478.

Sue, D. W., \& Kirk, B.A. (1973). Differential characteristics of Japanese-American and Chinese-American college students. Journal of Counseling Psychology, 20(2), 142-148.

Sue, S., \& McKinney, H. (1975). Asian Americans in the community mental health care system. American Journal of Orthopsychiatry, 45, $111-118$.

Sue, D. W., \& Sue, D. (1989). Counseling the culturally different. New York: Wiley.

Takahata, G. M., \& Armstrong, W. B. (1996). Campus climate classified staff survey, fall 1995. (ERIC Document Reproduction Service No. ED 398 967)

Tata, S. P., \& Leong, F. T. L. (1994). Individualism, collectivism, social network orientation and acculturation as predictors of attitudes toward seeking professional psychological help among Chinese Americans. Journal of Counseling Psychology, 41(3), 280-287.

Tedeschi, G. J., \& Willis, F. N. (1993). Attitudes toward counseling among Asian international and native Caucasian students. Journal of College Student Psychotherapy, 7, 43-54.

Tinto, V. (1987). Leaving college: Rethinking the causes and cures of student attrition. Chicago: University of Chicago, Press.

Tracey, T. J., Leong, F. T. L., \& Glidden, C. (1986). Help-seeking and problem perception among Asian Americans. Journal of Counseling Psychology, 33, 331-336.

Trent, J. W. (1970). The decision to go to college: An accumulative multivariate process. U.S. Department of Health, Education and Welfare, 1-30.

Uba, L. (1994). Asian Americans: Personality patterns, identity, and mental health. New York: The Guilford Press.

U.S. Bureau of the Census. (1992). Statistical abstract of the United States: 1992 (112th edition). Washington, D.C.: author.

Waelde, L. C. (1994). Stressful life events: Moderators of the relationships of gender and gender roles to self-reported depression and suicidality among college students. Sex Roles: A Journal of Research, 30(1-2), 1-22. 
Walsh, W. B. (1973). Theories of person-environment interaction: Implications for the college student. ACT Monograph (20). Iowa City, IA: American College Testing Program.

Wang, L. L. (1993). Trends in admissions for Asian Americans in colleges and universities: Higher Education Policy. The State of Asian Pacific America: A Public Policy Report. Los Angeles: Leader Education for Asian Pacifics and the UCLA Asian American Studies Center, University of California.

Wang, L. L. (1995). Meritocracy and diversity in higher education: Discrimination against Asian Americans in the post-Bakke era. In D. T. Nakanishi \& T. Y. Nishida (Eds), The Asian American educational experience. New York: Routledge.

Wilson, R. (1998, October 2). U. of Wisconsin considers proposal to ease limits on faculty speech. The Chronicle of Higher Education, Al4-16.

Yeh, C., \& Wang, Y. H. (2000). Asian American coping attitudes, sources, and practices: Implications for indigenous counseling strategies. Journal of College Student Development, 41(1), 94-103. 